\title{
Molatisu Implementation Increasing Integrated Health Post Cadre Skills Under Five Years Old Related Balance Menu Preparation
}

\author{
CrossMark \\ I Komang Agusjaya Mataram a, Anak Agung Nanak Antarini b ${ }^{b}$, Ni Putu Agustini ${ }^{c}$ \\ Manuscript submitted: 09 November 2019, Manuscript revised: 18 December 2019, Accepted for publication: 31 January 2019
}

\section{Corresponding Author a}

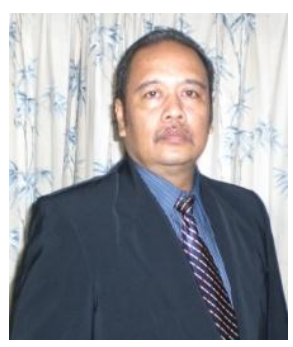

\section{Keywords}

balanced menus; level of participation; molatisu implementation; posyandu cadres; skill in preparing menus;

\begin{abstract}
The aim of the research is to improve the skills of integrated health post (posyandu) cadres in preparing balanced children under five years old menu related to the level of participation of her mother coming to posyandu in Denpasar. The results of the study are 1) The level of posyandu cadre knowledge about balanced menus on average before 60.25 and after the intervention amounted to $72.95,2$ ) The skills preparing a balanced menu before were entirely incapable and after the intervention, there was an increase in skills. Posyandu cadres have been able to prepare a balanced menu for the counseling in four tables during posyandu activities, 3) The level of participation coming to the posyandu before was 73.17 and after one month was 64.19, and after two months of the intervention was 59.95, 4) There was a significant increase in the level of posyandu cadre knowledge about balanced menus, 5) There was an increase in the skills of preparing a balanced menu, 6) The level of participation did not differ between the level of participation one month after the intervention (September) with two months after the intervention (October).
\end{abstract}

\section{Contents}

Abstract

1 Introduction.

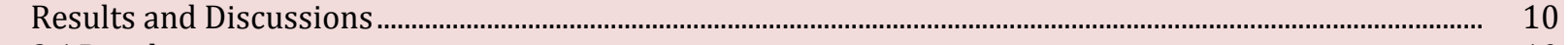

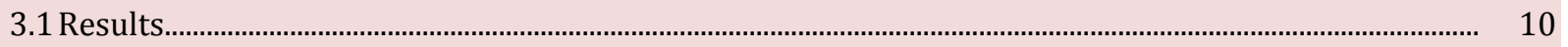

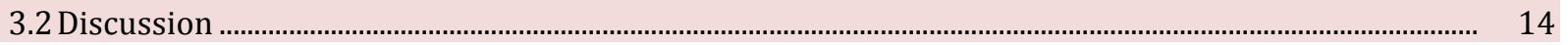

a Health Polytechnic, Denpasar, Indonesia

b Health Polytechnic, Denpasar, Indonesia

c Health Polytechnic, Denpasar, Indonesia 


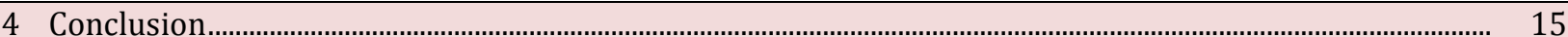

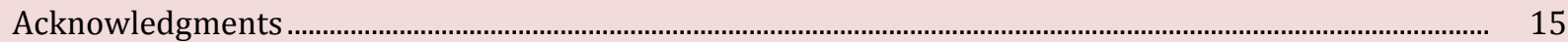

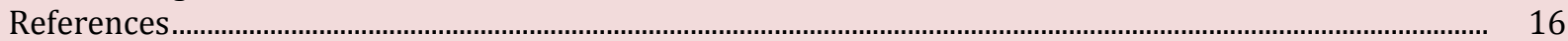

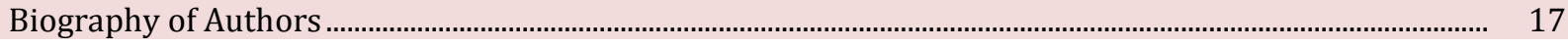

\section{Introduction}

Nutrition problems especially malnutrition and lack of nutrition and very short and short stunting based on Basic Health Research data shows that in Bali Province there are fluctuations as indicated by the prevalence of nutritional status in 2018 which appears $2.0 \%$ malnutrition and malnutrition $11,1 \%$, while nationally the prevalence of malnutrition is $3.9 \%$ and malnutrition is $13.8 \%$. The prevalence is very short $5.6 \%$ and $16.3 \%$ short, while nationally the prevalence is very short $11.5 \%$ and short $19.3 \%$. Even though this nutritional problem is still below the national rate, we must be aware to prevent future improvements. According to UNICEF (1998), nutritional problems are generally caused by two factors, that is food consumption and infection, where these two factors interact with each other. Inadequate food consumption can be influenced by the mother's parenting given to her child under five years. This parenting can be influenced by the knowledge and skills of mothers to provide nutritious food so that they can meet the nutritional needs of a child under five years.

Posyandu is a form of Community-Based Health Efforts (UKBM) which is managed and managed held from, by, for, and with the community within implementation of health development, in order to empower community and provide convenience to the community in obtaining basic health services, especially for accelerate the decline in maternal and infant mortality. To support the development of Posyandu, steps are needed education to the community, among others, with efforts to improve cadre capacity through Posyandu cadre training specifically the skill of arranging menus for toddlers (Indonesian Minister of Health, 2015; Indonesian Minister of Health, 2012; Indonesian Minister of Health, 2006; Ali, 2009). The monthly posyandu activity with a 5 table system which is implemented in an integrated manner is one of the activities that can increase the knowledge of mothers of children under five. At table IV of the 5 table system, the "counseling" activity is carried out to provide information to the toddler mother regarding nutritional status by looking at the growth chart on the card towards health (KMS). The activities at table IV can be enhanced by increasing the knowledge and skills of posyandu cadres to educate or socialize about balanced menus.

Information received by mothers of a child under five will be useful for preparing a balanced menu so that the nutritional needs can be fulfilled optimally. Mothers who provide a balanced menu will be able to meet the nutritional needs of toddlers, especially protein, thus ensuring avoidance of nutritional problems. The benefits received in the implementation of posyandu activities are expected to motivate mothers of children under five to come to posyandu regularly every month. The ability of posyandu cadres, in general, has not been prepared optimally to provide counseling on balanced menus (Mataram, 2017; Aridiyah et al., 2015).

The ability of posyandu cadres, in general, has not been prepared optimally to provide counseling on balanced menus. The final impact expected is that posyandu cadres carry out counseling at table IV and the visits of mothers of toddlers to posyandu are increasing. The formulation of the problem that can be arranged is whether the implementation of Molatisu can improve the skills of posyandu cadres to prepare a balanced menu in relation to the level of participation of mothers of children under five coming to posyandu in Denpasar? In general, the aim of the research is to implement Molatisu in order to improve the skills of posyandu cadres in preparing a balanced menu in relation to the level of participation of mothers of children under five coming to posyandu in Denpasar. Specific research objectives are a) Identifying the level of posyandu cadre knowledge about balanced menus before and after intervention, b) Measuring the skills of posyandu cadres preparing a balanced menu before and after the intervention, c) Identifying the level of participation of mothers coming to the Posyandu before and after the intervention, d) Analyzing differences in the level of knowledge of posyandu cadres about balanced menus before and after intervention, e) Analyzing differences in the skills of posyandu cadres preparing a balanced menu before and after the intervention, $\mathrm{f}$ ) Analyzing differences in the level of participation of posyandu cadres preparing a balanced menu before and after intervention.

Mataram, I. K. A., Antarini, A. A. N., \& Agustini, N. P. (2020). Molatisu implementation increasing integrated health post cadre skills under five years old related balance menu preparation. International Journal of Health Sciences, 4(1), 8-17. https://doi.org/10.29332/ijhs.v4n1.397 


\section{Materials and Methods}

This type of research is experimental with the design of "The One Group Pretest-Posttest Design". (Sastroasmoro \& Ismael, 2006; Notoatmodjo, 1993). The research was divided into 3 (three) stages, namely: a) Preparation, implementation, and evaluation. In the preparation stage the following activities are carried out: 1) Arrangement of research permit, 2) Preparing intervention material, 3) Preparing tools and materials, 4) Preparing administration, b) The implementation phase includes 1) Procurement of tools and materials, 2) Arranging the place of intervention, 3) Submission of material, 4) Practice preparing balanced menus for toddlers and c) The evaluation phase of the activity includes: 1) Assessing knowledge, 2) Assessing skills in preparing balanced menus, 3) identifying participation and 4) Analyzing pretest-posttest scores of balanced menu knowledge, skills in preparing balanced menus and levels of participation.

The study was conducted in 2 (two) places, namely, the implementation of the intervention carried out at the Nutrition Department of the Polytechnic of the Ministry of Health Denpasar and the measurement of the participation of mothers of children under five to the posyandu carried out at the posyandu in the East Denpasar District area, Denpasar City with a research period of 6 months in 2019. The intervention given is the practice of preparing a balanced menu to meet the adequacy of nutrition consisting of a balanced menu of aged 1 year, 3 years and 5 years. The balanced menu for one-year-old consists of white rice $(75 \mathrm{~g})$, sweet and sour snapper $50 \mathrm{~g}$ ), tempeh satay (25 g), soup (beans, carrots, cabbage) (30 g) and papaya (25 g). The balanced menu for three-year-old consists of white rice $(100 \mathrm{~g})$, teriyaki sauce chicken $(40 \mathrm{~g})$, tofu fried (chicken, carrots, onion, seasoning) (25 g) and a watermelon $(25 \mathrm{~g})$. The balanced menu for five-year-old consists of white rice (100 g), chicken stew (50 g), dried tempeh (50 g), clear spinach ( $25 \mathrm{~g})$ and fruit satay (melon, papaya, grapes) 25 g) (Indonesian Minister of Health, 2014; Mahmud et al., 2009).

The media used at the time of the intervention were training modules and counseling modules, abbreviated as "molatisu". The training module is used when practicing preparing a balanced menu and the counseling module is used when the cadres conduct extension activities at the posyandu by presenting a balanced menu (Truelove, 1995; Suparman, 1997; Lockwood \& Ismail, 1994). The first evaluation was conducted by visiting the implementation of posyandu activities in September 2019 and the second in October 2019. Evaluation is carried out on balanced menus especially the portion of each menu that is presented on table IV to meet the nutritional adequacy of children under five. (Moekijat, 1992)

Based on a balanced menu that is presented then counseling to mothers of a child under five who come to the posyandu. The research location and sample were determined purposively namely Puskesmas I and Puskesmas II Denpasar Timur with a total sample of 53 posyandu ( $52 \%$ of total posyandu). The sample is 1 (one) posyandu cadre from posyandu for each selected village. Data on increased knowledge and skills in preparing a balanced menu before and after the intervention and the level of participation were analyzed by paired tests. (Widarjono, 2010)

\section{Results and Discussions}

\subsection{Results}

\section{Sample characteristics}

The sample age ranged from 22-53 years, and most were in the 41-50 year age group that is as many as 32 (60.4\%) samples. The level of education in the sample varied greatly from elementary to tertiary education, and most had a high school education level of 38 (71.7\%) samples. (Table 1)

Table 1

Distribution of samples by characteristics

\begin{tabular}{ccc}
\hline Characteristics & f & $\%$ \\
\hline a. Age (years) & & \\
\hline $1 . \quad \leq 30$ & 3 & 5.7
\end{tabular}




\begin{tabular}{|c|c|c|}
\hline 2. $31-40$ & 12 & 22.6 \\
\hline 3. $41-50$ & 32 & 60.4 \\
\hline 4. $>50$ & 6 & 11.3 \\
\hline Total & 53 & 100.0 \\
\hline \multicolumn{3}{|l|}{ b. Education } \\
\hline 1. Elementary school & 2 & 3.8 \\
\hline 2. Middle School & 5 & 9.4 \\
\hline 3. High School & 38 & 71.7 \\
\hline 4. University & 8 & 15.1 \\
\hline Total & 53 & 100.0 \\
\hline \multicolumn{3}{|l|}{ c. Occupation } \\
\hline 1. Civil servants & 4 & 7.5 \\
\hline 2. Private employees & 17 & 32.1 \\
\hline 3. Entrepreneurs & 8 & 15.1 \\
\hline 4. Housewife & 24 & 45.3 \\
\hline Total & 53 & 100.0 \\
\hline \multicolumn{3}{|c|}{ d. Long time being a cadre (yr) } \\
\hline 1. $1-5$ & 28 & 52.8 \\
\hline 2. $6-10$ & 14 & 26.4 \\
\hline 3. $11-15$ & 9 & 17 \\
\hline 4. $16-25$ & 2 & 3.8 \\
\hline Total & 53 & 100.0 \\
\hline \multicolumn{3}{|l|}{ e. Cadre Training } \\
\hline 1. Ever & 46 & 86.8 \\
\hline 2. Not yet & 7 & 13.2 \\
\hline Total & 53 & 100.0 \\
\hline
\end{tabular}

Job samples include civil servants, work in the private sector and entrepreneurs as well as housewives. Most of the samples as housewives were $24(45.3 \%)$ samples. The length of time being a posyandu cadre ranged from 1-25 years, and most in the 1-5 year group were 28 (52.8\%) samples. Posyandu cadres appointed by the hamlet head when carrying out their duties will receive training first. But in reality, there are still cadres who have not received training even though there are not many, as many as 7 (13.2\%) samples. (Table 1)

\section{Knowledge}

Knowledge of the sample was measured by 15 questions including posyandu activities, animal protein sources, vegetable protein sources, sources of food for growth, to move, portions of carbohydrates, side dishes, vegetables and fruit on a balanced menu cone and my plate contents. The level of pre-test knowledge ranged from 40.0-100.0 with an average of 60.25 ( $S D=12.05)$, while the post-test ranged from 46.67 to 100.0 with an average of $72.95(\mathrm{SD}=11.94)$ (Table 2$)$.

Table 2

Sample distribution according to pre-test and post-test knowledge level scores

\begin{tabular}{lllll}
\hline Knowledge level & Pre-Test & Post-Test & Enhancement & $\begin{array}{l}\text { Paired Test } \\
\text { (sig. 2 tailed) }\end{array}$ \\
\hline The highest & 100.0 & 100.0 & 0.0 & \\
The lowest & 40.0 & 46.67 & 6.67 & 0.000 \\
Average & 60.25 & 72.95 & 12.70 & \\
Standard Deviation & 12.05 & 11.94 & - & \\
\hline
\end{tabular}

Mataram, I. K. A., Antarini, A. A. N., \& Agustini, N. P. (2020). Molatisu implementation increasing integrated health post cadre skills under five years old related balance menu preparation. International Journal of Health Sciences, 
The level of pre-test knowledge, if categorized, was mostly in the sufficient category, namely 28 (52.8\%), while in the post-test it was $26(49.1 \%)$. The level of knowledge in both categories in the post-test (41.5) seemed to increase quite a lot in number compared to the pre-test (9.4\%) (Table 3).

Table 3

Sample distribution by pre-test and post-test knowledge level categories

\begin{tabular}{lllll}
\hline \multirow{2}{*}{ Knowledge level } & \multicolumn{3}{c}{ Pre-Test } & \multicolumn{2}{c}{ Post-Test } \\
\cline { 2 - 5 } & $\mathrm{f}$ & $\%$ & $\mathrm{f}$ & $\%$ \\
\hline Good & 5 & 9.4 & 22 & 41.5 \\
Enough & 28 & 52.8 & 26 & 49.1 \\
Less & 20 & 37.8 & 5 & 9.4 \\
Total & 53 & 100.0 & 53 & 100.0 \\
\hline
\end{tabular}

\section{Skills in preparing a balanced menu}

In the training, a menu of age 1 (one) year, 3 (three) years and 5 (five) years was arranged. A balanced menu for 1 (one) year to meet the energy needs of $650 \mathrm{kcal}$ energy and 16 grams of protein, can be fulfilled by consuming a balanced menu as follows: of white rice ( $75 \mathrm{~g})$, sweet and sour snapper ( $50 \mathrm{~g})$, satay tempeh (25 g), soup (beans, carrots, cauliflower) (25 g) and papaya (25 g). A balanced menu for 3 (three) years of age to meet the energy needs of $1000 \mathrm{kcal}$ energy and 25 grams of protein, can be fulfilled by consuming a balanced menu as follows: of white rice $(10 \mathrm{~g})$, teriyaki sauce chicken $(40 \mathrm{~g})$, tofu $(50 \mathrm{~g}), 25$ greens $(25 \mathrm{~g})$ and watermelon $(25 \mathrm{~g})$. A balanced menu for 5 (five) years of age to meet the nutritional needs of $1550 \mathrm{kcal}$ energy and 30-gram protein, can be fulfilled by consuming a balanced menu as follows: of white rice (100 g), chicken stew (50 g), dried tempeh $(50 \mathrm{~g})$, spinach clear $(25 \mathrm{~g})$ and fruit satay (melon, papaya, grapes) (25 g). (Mahmud et al., 2009; Almatsier, 2005)

All samples do not yet know the amount or portion that must be presented for aged 1 (one), 3 (three) years and 5 (five) years. Training on the practice of cooking a balanced menu is expected to improve the skills of cadres to prepare a balanced menu. This balanced menu will be presented when giving counseling at table IV at the monthly posyandu activities. A balanced menu evaluation is carried out during the visit to the posyandu by assessing the portion served. The results obtained are serving balanced menus aged 1 (one) year served with more and appropriate portions.

Rice was served in suitable portions of $18(34.0 \%)$ and more than $35(66.0 \%)$. There are already animal side dishes that are served with the appropriate portion of $14(26.4 \%)$, but more are over-serving which is 39 (73.6\%). Likewise with vegetable and vegetable side dishes, while the portion of fruit is appropriate. For 3 (three) years old menu, it is served with more and more appropriate portions. For rice samples that have served with appropriate portions of $38(71.7 \%)$ and more as many as $15(28.3 \%)$. Animal side dishes have more samples that serve with the appropriate portion of 27 (50.9\%), but there are still over-serving that are as many as $26(49.1 \%)$. Likewise with vegetable and vegetable side dishes, while the portion of fruit is appropriate.

For 5 (five) years old menu, it is served in a more and appropriate portion. As for rice, $48(90.6 \%)$ and more than 5 (9.4\%) have been served. Animal side dishes have more samples that serve with the appropriate portion of $45(84.9 \%)$, but there are still over-serving that are as many as $8(15.1 \%)$. Likewise with vegetable and vegetable side dishes, while the portion of fruit is appropriate (Table 4).

Table 4

Distribution of Samples according to Skills in Arranging Balanced Menus at the Posyandu

\begin{tabular}{llllllllll}
\hline Menu & $\begin{array}{c}\text { Amount } \\
\text { (gram) }\end{array}$ & More & & Compatible & Less & \multicolumn{3}{c}{ Total } \\
\hline 1. Age 1 year & & $\mathrm{f}$ & $\%$ & $\mathrm{f}$ & $\%$ & $\mathrm{f}$ & $\%$ & $\mathrm{f}$ & $\%$ \\
\hline a. Rice & 75 & 35 & 66.0 & 18 & 34.0 & 0 & 0.0 & 53 & 100.0 \\
b. Animal side dishes & 50 & 39 & 73.6 & 14 & 26.4 & 0 & 0.0 & 53 & 100.0
\end{tabular}




\begin{tabular}{clllllllll}
\hline c. Vegetable side dishes & 25 & 41 & 77.4 & 12 & 22.6 & 0 & 0.0 & 53 & 100.0 \\
d. Vegetables & 25 & 41 & 77.4 & 12 & 22.6 & 0 & 0.0 & 53 & 100.0 \\
e. $\quad$ Fruit & 25 & 0 & 0.0 & 53 & 100.0 & 0 & 0.0 & 53 & 100.0 \\
\hline 2. Age 3 years & & & & & & & & & \\
\hline a. Rice & 100 & 15 & 28.3 & 38 & 71.7 & 0 & 0.0 & 53 & 100.0 \\
b. Animal side dishes & 40 & 26 & 49,1 & 27 & 50.9 & 0 & 0.0 & 53 & 100.0 \\
c. Vegetable side dishes & 50 & 22 & 41.5 & 31 & 58.5 & 0 & 0.0 & 53 & 100.0 \\
d. Vegetables & 25 & 33 & 62.3 & 20 & 37.7 & 0 & 0.0 & 53 & 100.0 \\
e. Fruit & 25 & 0 & 0.0 & 53 & 100.0 & 0 & 0.0 & 53 & 100.0 \\
\hline 3. Age 5 years & & & & & & & & & \\
\hline a. Rice & 100 & 5 & 9.4 & 48 & 90.6 & 0 & 0.0 & 53 & 100.0 \\
b. Animal side dishes & 50 & 8 & 15.1 & 45 & 84.9 & 0 & 0.0 & 53 & 100.0 \\
c. Vegetable side dishes & 50 & 6 & 11.3 & 47 & 88.7 & 0 & 0.0 & 53 & 100.0 \\
d. Vegetables & 25 & 32 & 60.4 & 21 & 39.6 & 0 & 0.0 & 53 & 100.0 \\
e. Fruit & 25 & 0 & 0.0 & 53 & 100.0 & 0 & 0.0 & 53 & 100.0 \\
\hline
\end{tabular}

\section{Participation comes to Posyandu}

The participation rate of mothers coming to the posyandu before the intervention (August) is as low as $40.43 \%$ and the highest is $100.0 \%$ with an average of $73.17 \%$ (Stand. Dev. $=19.35$ ) whereas at the posyandu implementation one month after training (September) the lowest is $21,13 \%$ and the highest $100.0 \%$ with an average of $64.19 \%$ (Stand. Dev.=19.56). (Table 5).

Table 5

Sample distribution by participation rate at Posyandu activities

\begin{tabular}{|c|c|c|c|c|c|c|}
\hline Participation Rate & $\begin{array}{l}\text { H-2 (\%) } \\
\text { February }\end{array}$ & $\begin{array}{l}\text { H-1 (\%) } \\
\text { July }\end{array}$ & $\begin{array}{l}\text { H0 (\%) } \\
\text { August }\end{array}$ & $\begin{array}{l}\text { H1(\%) } \\
\text { Sept }\end{array}$ & $\begin{array}{l}\text { H2 (\%) } \\
\text { October }\end{array}$ & $\begin{array}{l}\text { paired-test } \\
\text { (sig. 2-tailed)) }\end{array}$ \\
\hline The highest & 100,0 & 100,0 & 100,0 & 100,0 & 100,0 & $\mathrm{H}-2-\mathrm{H} 0: 0,353^{\mathrm{ns})}$ \\
\hline The lowest & 44,68 & 25,00 & 40,43 & 21,13 & 12,50 & H-1-H1:0,038*) \\
\hline Average & 77,02 & 58,83 & 73,17 & 64,19 & 59,95 & $\mathrm{H}-1-\mathrm{H} 2: 0,624^{\mathrm{ns})}$ \\
\hline Standard Deviation & 17,20 & 20,71 & 19,35 & 19,56 & 22,67 & $\begin{array}{l}\left.\text { H0-H1: } 0,018^{*}\right) \\
\text { H1-H2: } 0,103^{\text {ns) }}\end{array}$ \\
\hline
\end{tabular}

Note:

Participation Rate $=$ arrival/number of a child under five years

H-2: February

H-1: July

H0: Month of training (August)

H1: One month after attending training (September)

H2: Two months after attending training (October)

*) Significantly different ns) Not significantly different

The level of participation of mothers coming to the posyandu when compared to the target (85\%), the majority are still below the target of $49(92.5 \%)$, only $4(7.5 \%)$ is above the target (Table 6).

Table 6

Sample distribution according to participation rate and target posyandu activities

\begin{tabular}{lll}
\hline $\begin{array}{l}\text { Participation rate } \\
(85 \% \text { target })\end{array}$ & $\mathrm{f}$ & $\%$ \\
\hline Not achieved & 49 & 92.5 \\
Achieved & 4 & 7.5 \\
Total & 53 & 100.0 \\
\hline
\end{tabular}

Participation Rate $=$ arrival/number of a child under five years at posyandu

Mataram, I. K. A., Antarini, A. A. N., \& Agustini, N. P. (2020). Molatisu implementation increasing integrated health post cadre skills under five years old related balance menu preparation. International Journal of Health Sciences, 


\subsection{Discussion}

\section{Characteristics of Samples}

The age, occupation, and education of the sample will be able to influence the quality and activities when carrying out tasks at the posyandu. The implementation of the 5 posyandu table system in the field did not seem to be optimal, especially the activity at table IV, namely activities counseling. Posyandu cadres who have been trained should continue to implement the 5-table system. In order to continue to carry out counseling at table IV by utilizing appropriate media such as balanced menu examples with the expectation of mothers of toddlers who come to posyandu to obtain complete information and real examples of balanced menus that must be given to their child under five years.

\section{Level of Knowledge}

The level of knowledge has increased which can be seen from the level of knowledge before the intervention (pre-test) compared to the level of knowledge after the intervention (post-test). On average post-test knowledge level (72.95) is higher than the pre-test knowledge level (60.25).

Based on the statistical analysis paired test obtained sig. 2 tailed for 0,000 . This means that the level of knowledge before and after the intervention is significantly different. It can be concluded that training interventions with the implementation of training modules can increase sample knowledge.11; 21 The level of knowledge of the sample after the post-test has not yet reached an optimal score and needs to be increased, especially regarding the tumpeng balanced nutrition and fill my plate.

To increase the knowledge and skills of preparing a balanced menu using lecture methods and practice in the dietetics laboratory. Knowledge enhancement can also be done with peer education methods or assisted with media such as booklets and audio media. (Zulaekah,2012; Aliya \& Muwakhidah, 2017; Permatasari, 2017)

\section{Skills in Preparing a Balanced Menu}

In the training, a balanced menu and practice are carried out for ages 1 (one) year, 3 (three) years and 5 (five) years. Individual cadres gain firsthand experience by cooking the menus that have been prepared and the ingredients that have been weighed according to menu requirements. In implementing the balanced menu preparation at the posyandu it is expected to be able to estimate the amount of food that will be used to prepare the menu.

All cadres do not know the number of each menu to be served for toddlers aged 1 (one), 3 (three) years and 5 (five) years. At the time the posyandu cadre training was carried out by the puskesmas and the lurah/Perbekel this information had not been obtained. The practice of preparing a balanced menu to meet the nutritional needs of toddlers is new information and will be very helpful when providing counseling at table IV. (Indonesian Minister of Health, 2011)

A balanced menu evaluation is carried out during the visit to the posyandu by assessing the portion served and the results that are not yet optimal. There are still some cadres who serve rice, animal side dishes, vegetable side dishes, and vegetables with more portions. This situation is supported because the sample does not have food scales so the portion served is based on estimates. During the outreach, the posyandu cadre applied the counseling module that had been prepared.

\section{Participation in coming to Posyandu}

The level of participation of mothers coming to the posyandu on average before training (August) was (73.17\%), one month after training (September) was (64.19\%) and the second month (October) was 59.95\%. The low level of participation can be caused by the satisfaction obtained at the posyandu (Widartini, 2013). To increase the visit of mothers to posyandu, it is hoped that posyandu cadres, hamlet heads, and health workers will continue to provide information, encouragement, and motivation to mothers to invite their child to come to posyandu (Widiastuti, 2006). Besides that, the characteristics of the mother also play an important role in 
bringing her child to the posyandu including the level of education, employment status, and the level of knowledge about posyandu (Aprianti et al., 2014).

Based on the paired test $(\mathrm{H} 0-\mathrm{H} 1)$ statistical tests obtained sig. 2 tailed $=0.018$. This shows a significant difference between the level of participation before (August) and one month after training (September). Based on paired test $(\mathrm{H} 1-\mathrm{H} 2)$ statistical test, sig. 2 tailed $=0.103$. This shows no significant difference, where the level of participation of mothers of children under five coming to the posyandu on average one month after training (September) was (64.19\%) and two months after training (October) amounted to (59.95\%). This shows an insignificant difference between the level of participation one month after training and two months after training. Mothers who do not come to the posyandu because there are traditional events and busywork. The balanced menu presentation as a counseling media at table IV has not been able to attract the attention of mothers of toddlers coming to the posyandu. Nevertheless, it continues to be carried out every month during posyandu activities.

At the time of serving a balanced menu, it is expected that posyandu cadres are more communicative in presenting menus that should be consumed by child under five according to their nutritional needs, in accordance with what is expected by the public to obtain ease in obtaining information and basic health services, especially with regard to decreasing mother, infant and children mortality rate (Indonesian Minister of Health, 2012).

The mother will get a real example of a balanced menu that should be consumed by the toddler. Then the information obtained is applied in each household so that the consumption of nutrients for the toddler can meet the body's nutritional needs. An evaluation of the application of a balanced menu can be proven if a child under five years experiences weight gain in weighing the following month (Ni'mah \& Nadhiroh, 2016; Kusumawati et al.,2015; Suwitri \& Sidiartha, 2018).

\section{Conclusion}

Conclusions that can be drawn up that is 1) The level of posyandu cadre knowledge about balanced menus on average before the intervention 60.25 and after the intervention of 72.95., 2) Posyandu cadre skills prepare a balanced menu before all interventions have not been able and after the intervention there is an increase in skills. Posyandu cadres have been able to prepare a balanced menu for table IV during posyandu activities, 3) The level of participation of mothers coming to the posyandu before the intervention (August) was 73.17, after one month of intervention (September) at 64.19 and after two months of intervention (October) at 59.95., 4) There is a significant increase in the level of posyandu cadre knowledge about balanced menus before and after the intervention, 5) There is an increase in the skills of posyandu cadres in preparing a balanced menu before and after the intervention, 6) There is no significant difference between the level of participation after one month of intervention (September) and two months of intervention (October).

\section{Recommendation}

Based on the results and discussion, it can be suggested that when implementing Posyandu cadre training conducted by Puskesmas or Lurah / Perbekel, the following matters need to be considered: 1) Knowledge that needs to be focused on is the Tumpeng balanced nutrition and the fill my plate, 2) The skill to compile a balanced menu that needs to be focused on the portion of rice, animal side dishes, vegetable side dishes, and vegetables.

\section{Acknowledgments}

Further thanks to the director, chairman of the Nutrition Department of Polytechnic Denpasar for the support that has been given. Also to Head of the East Denpasar I \& II Community Health Center for fluency in the field.

Mataram, I. K. A., Antarini, A. A. N., \& Agustini, N. P. (2020). Molatisu implementation increasing integrated health post cadre skills under five years old related balance menu preparation. International Journal of Health Sciences, 


\section{References}

Ali, A.R. (2009). Posyandu Development "Integrated Health Service Posts in the village".

Aliya, H., \& Muwakhidah, M. (2017). Pengaruh Pendidikan Gizi Dengan Media Audio Kinestetik (Senam dan Lagu Pesan Gizi Seimbang) terhadap Peningkatan Pengetahuan Gizi Seimbang pada Anak SD Muhammadiyah 4 Kandangsapi Surakarta. Jurnal Kesehatan, 10(2).

Almatsier, S. (2005). Basic Principles of Nutrition. Jakarta: Gramedia Main Library.

Aprianti, Yasir F., \& Rijanti. (2014). Factors that are related to the presence of mothers weighing children under five in the Posyandu, the work area of the Central Alalak Community Health Center and Piskesmas S. Parman, Banjarmasin. Husada Health Scale Journal, 5(1).

Aridiyah, F. O., Rohmawati, N., \& Ririanty, M. (2015). Faktor-faktor yang Mempengaruhi Kejadian Stunting pada Anak Balita di Wilayah Pedesaan dan Perkotaan (The Factors Affecting Stunting on Toddlers in Rural and Urban Areas). Pustaka Kesehatan, 3(1), 163-170.

Indonesian Minister of Health (2006). General Guidelines for Managing Posyandu. Jakarta, Collaboration with Posyandu Operational Work Groups (Pokjanal).

Indonesian Minister of Health (2011). General Guidelines for Posyandu Management. Jakarta.

Indonesian Minister of Health (2012). Come to Posyandu Every Month. Jakarta. Health Promotion Center

Indonesian Minister of Health (2012). Posyandu Cadre Curriculum and Training Module. Jakarta: Health Promotion Center.

Indonesian Minister of Health (2014). Balanced Nutrition Guidelines. Jakarta, Directorate General of Mother Child Nutrition and Health

Indonesian Minister of Health (2015). Cadre Handbook. Jakarta: Center for Health Crisis Management.

Kusumawati, E., Rahardjo, S., \& Sari, H. P. (2015). Model pengendalian faktor risiko stunting pada anak bawah tiga tahun. Kesmas: National Public Health Journal, 9(3), 249-256. http://dx.doi.org/10.21109/kesmas.v9i3.572

Lockwood D., \& Ismail, A. (1994). Design of Effective Training. Jakarta. Pramedia Main library

Mahmud, M. K., Hermana, Z. N. A., Apriyanto, R., Ngadiarti, I., Hartati, B., \& Tinexcelly, B. (2009). Indonesia food composition table. PT Elex Media Komputindo, Jakarta.

Mataram, I. K. A. (2017). Stunting cause factors in the village of traditional Bali. International research journal of engineering, IT \& scientific research, 3(2), 157-164.

Moekijat, (1992). Training Evaluation. Bandung, Mandar Maju.

Ni'mah, K., \& Nadhiroh, S. R. (2016). Faktor yang berhubungan dengan kejadian stunting pada balita. Media Gizi Indonesia, 10(1), 13-19. http://dx.doi.org/10.20473/mgi.v10i1.13-19

Notoatmodjo, S. (1993). Health Research Methodology. Jakarta: Rineka Cipta.

Permatasari, T. A. E. (2017). Increased Knowledge and Balanced Nutrition Behavior Using the Peer Education Method. Kes Mas: Journal of the Faculty of Public Health. 11(2), 114-120

Sastroasmoro, S., \& Ismael, S. (2006). Basics of clinical research methodology. Jakarta: Sagung Seto, 101-105.

Suparman, A. (1997). Interactive Learning Models. Jakarta, STIA-LAN Press.

Suwitri, N. P. E., \& Sidiartha, I. G. L. (2018). Omega-6 and omega-3 fatty acid content and ratio of commercial complementary foods. International journal of health sciences,2(1), 21-28. https://doi.org/10.29332/ijhs.v2n1.90

Truelove, S. (Ed.). (1995). Handbook of training and development. Blackwell.

Widarjono, A. (2010). Applied multivariate statistical analysis. Yogyakarta: Sekolah tinggi ilmu manajemen YKPN.

Widartini, N. G. A. P. (2013). Evaluation of Community Satisfaction Level of Posyandu Service Users in Puskesmas I Denpasar Selatan Work Area 2013. Jurnal Com. Health, 1(3),

Widiastuti, I. G. A. A. M. (2006). Utilization of Posyandu Services in Denpasar City. Thesis, Gajah Mada University, Yogyakarta.

Zulaekah, S. (2012). Pendidikan gizi dengan media booklet terhadap pengetahuan gizi. KEMAS: Jurnal Kesehatan Masyarakat, 7(2), 127-133. 


\section{Biography of Authors}

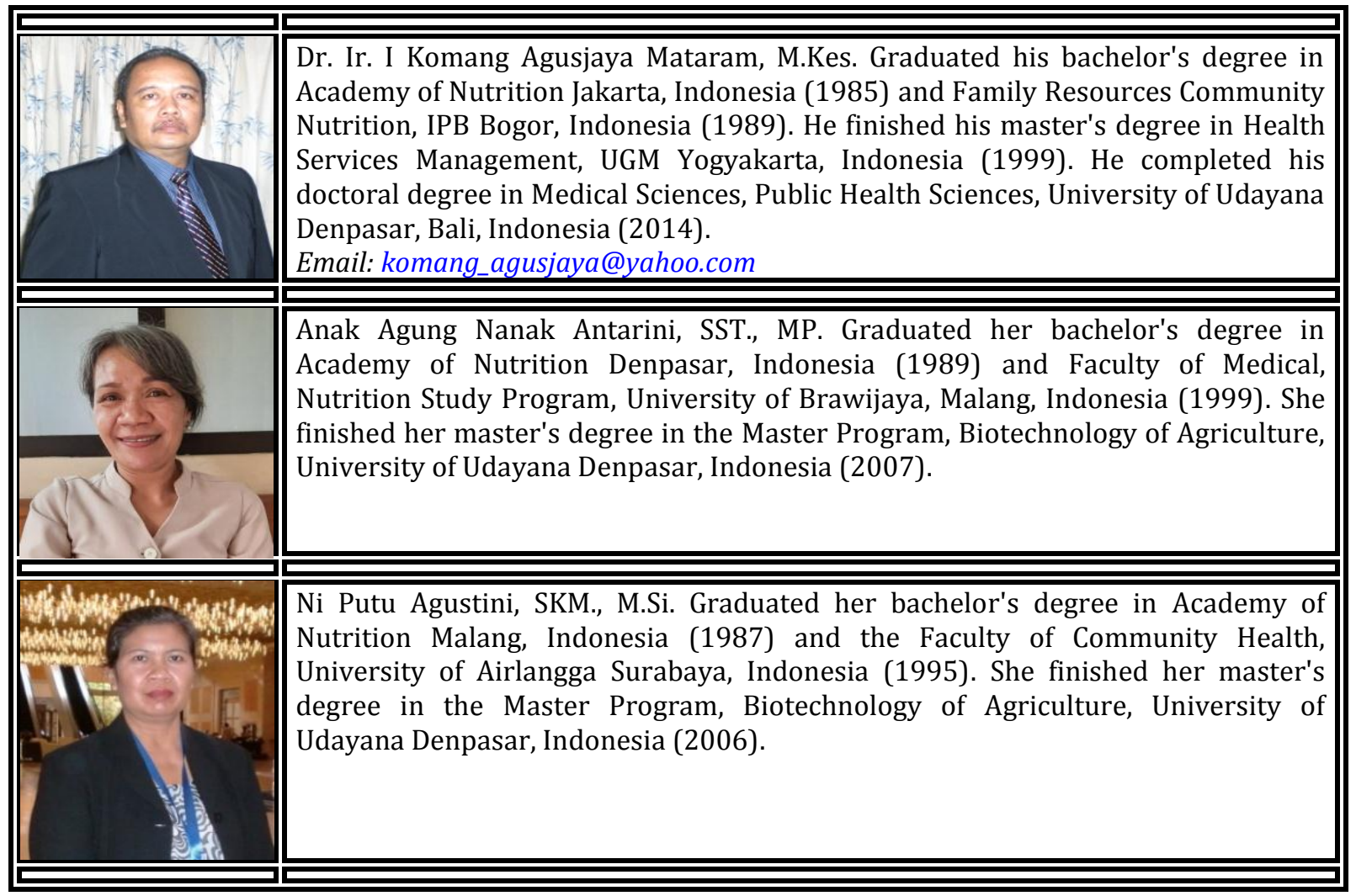

Mataram, I. K. A., Antarini, A. A. N., \& Agustini, N. P. (2020). Molatisu implementation increasing integrated health post cadre skills under five years old related balance menu preparation. International Journal of Health Sciences, 4(1), 8-17. https://doi.org/10.29332/ijhs.v4n1.397 